\title{
マンホール際管路の沈下挙動実験と対策管路の開発
}

\section{AN EXPERIMENT OF MANHOLE-FITTING PIPES SUBJECT TO LARGE GROUND SETTLEMENT AND DEVELOPMENT OF COUNTERMEASURE PIPELINES}

\author{
高田至郎*・田邊揮司良 ${ }^{* *} \cdot$ 狭間 祐二***・入 岡 博 明**** \\ By Shiro TAKADA, Kishiro TANABE, Yuji HAZAMA and Hiroaki IRIOKA
}

\begin{abstract}
Damages on buried pipelines connected to structures such as manholes and buildings are not uncommon due to differential ground settlement along the direction of pipeline stretches. First, we obtained fundamental data of the mechanical behavior of a buried UPVC (Unplasticized Poly Vinyl Chloride) pipeline jointed to a manhole when it was subjected to uneven ground settlement using Sinking Soil Box. Experimental results were then compared with the theoretical ones obtained by non-linear analyses using transfer matrix method. Both results were in good agreements. Next, the same experiments were carried out for a developed pipeline as a countermeasure for large ground settlements. The developed UPVC pipeline system may stand up to $45 \mathrm{~cm}$ of ground settlement, while ordinary pipeline system may yield to not less than $15 \mathrm{~cm}$ of ground settlement.

Keywords : ground settlement, polyvinyl chloride pipeline, countermeasure pipeline, response analysis
\end{abstract}

\section{1.はじめに}

従来より地震時や地盤の圧密による地盤沈下を想定し た大規模な管路沈下実験が種々行われており, 地盤沈下 による管路の被害機構も徐々に明らかとなってきてい る.

菊池ら ${ }^{11}$ は, 山砂と硫安の混合土を用い, 硫安の溶解 性を利用して沈下を引き起こし, 端部固定の有継手鋼管 (口径 $75 \mathrm{~mm}$ )・硬質塩化ビニル管（口径 $75 \mathrm{~mm}$ ) の沈 下実験を行っている. その結果, 硬質塩化ビニル管が良 好な沈下追従性を示すこと, また継手屈曲性による応力 緩和効果があることなどを示している.

高田ら ${ }^{2)}$ は, 大型沈下土槽を用い, ラバーリング (RR) 継手を有する硬質塩化ビニル管（PVP）（口径 $100 \mathrm{~mm}$ ) に対し不同沈下実験を行っている. その結果, 沈下土槽 は地盤大変形を受ける埋設管の挙動計測として有用な手 段であることを示し, さらに弾性地盤ばねを考慮した弾 性床上のはり理論および著者ら ${ }^{3)}$ の開発した伝達マト リックス法を用いた非線形地震応答解析プログラム

* 正会員 工博 神戸大学助教授 工学部土木工学科 ( ( 657 神戸市灘区六甲台町)

** 学生会員 工修 神戸大学大学院自然科学研究科 (同上)

*** 工修 久保田鉄工合成管研究部 ( T592 堺市石津西町 14-2)

**** 正会員 久保田鉄工合成管研究部 (同上)
(ERAUL) により解析を用い，RR 継手を有するPVP は $60 \mathrm{~mm}$ 程度の沈下まで耐え得ること, 継手は沈下境 界部の近傍に密に配置することにより忘力緩和効果が期 待できることを示している．また，沈下を受ける管路の 管体応力・継手変位の近似式を提示している.

東京ガス ${ }^{4)}$ では，油圧式沈下土槽を用い，有継手鋳鉄 管 (DIP) ・鋼管 (ST) (口径 150 600 mm) に対し不 同沈下実験を行っている. その結果, 地盤の締め固め度 が大きいほど管体ひずみは大きくなること，管体ひずみ は沈下土槽変位が $100 \mathrm{~mm}$ 前後で最大となり, その後は 増加しないことなどを示している．また，せん断を考慮 したはりの曲げ解析プログラムを用い, バイリニアでモ デル化した地盤および管体の剛性低下で考虑した継手に 対し沈下解析を行い, 沈下側の地盤ばね定数を固定側よ り小さめに見積もることで, 実験值とよく対応すること を示している.

水道用塩ビ管の技術研究会5)では, 東京ガスの実験装 置を用い, 有継手硬質塩化ビニル管（口径 $300 \mathrm{~mm}$ ) に 対して不同沈下実験を行っている. その結果, $20 \mathrm{~cm}$ の 沈下では沈下境界部から $1.5 \sim 2.0 \mathrm{~m}$ までの範囲の応力 に影響があること, 継手部の屈曲性は地盤の沈下に従い 有効に機能すること, さらに接合部の抜けについては, 最大抜け量が $10 \mathrm{~mm}$ 以内で, 沈下のみでは大きな抜け 
にならないことを示している.

大石 ${ }^{6}$ は菊池ら ${ }^{1)}$ と同様の沈下原理を用い, 端部固定 のアクリル製丸棒（口径 $20 \mathrm{~mm}$ ）および端部近傍に沈 下防止板を設けた場合について沈下実験を行っている. その結果，沈下防止板を用いた方が管体応力が低下する ことを示している. また，弾性床上のはり理論を用いた 結果と実験値の比較により, 中小口径管路の地盤沈下解 析には等価地盤ばねを用いた線形解析の適用で十分であ ることを示している.

管路が最も被害を受けると考えられるのは, 埋設管と 基礎のしっかりしたマンホールなどの構造物の接合部お よび継手部である.しかし，実験の大半は直線管路部の 不等沈下現象を対象にしており，沈下土槽を用いた端部 固定管の実験はいまだ行われていない.

そこで本論文では，地盤沈下を受けた際に被害を受け やすい，マンホールに取り付けられた管路の沈下挙動を 明らかにする. また，対象とした管路は RR 継手を有 する塩化ビニル管 (UPVP) で特に, 電力管を対象と している.

まず現在使用されている管路（従来型管路）を用いて 実験を行い，次に，管路の沈下挙動を踏まえたうえでな るべく大きな地盤沈下に耐え得る対策管路を開発し，そ の管路を用いて同様の実験を実施して耐沈下性能を検討 している.

なお，実験結果の検討には，論文 2)，5）でも管路の 沈下挙動をシミュレートしている ERAUL プログラム を用いている.

\section{2. 従来型マンホール取付管路の沈下挙動実験}

（1）実験手法

\section{a) 沈下土槽}

図一1 は, 長さ $800 \mathrm{~cm}$, 幅 $100 \mathrm{~cm}$, 深さ $150 \mathrm{~cm}$ の沈 下土槽を示している. 沈下土槽は 8 つのボルトでコンク リート製のピット内に吊り下げられており，その鉛直方 向の最大沈下量は $50 \mathrm{~cm}$ までとなっている. マンホー ルと管路部の不等沈下は, ボルトナットを緩めることに より与えられる. 沈下土槽の一端はゴム板を介してコン クリートと接触しており, 沈下時の土槽からの土塊の崩

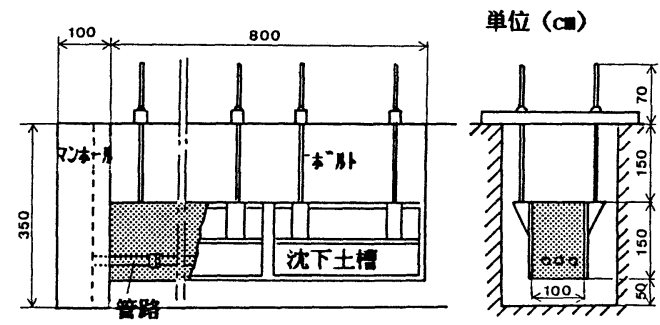

図一1 沈下土槽概要図
落を防いでいる，また，このコンクリート壁はマンホー ルとみたてており不動である.ここで，管体に作用する 土圧への土槽側壁の影響は, 地盤沈下量が小さい段階で は存在すると思われる. しかし, 本研究で対象としてい る管体または継手の許容值に達するときの比較的大きい 地盤沈下量ではすでに地盤破壊が進んでおり，そのとき はその影響はほとんどないと考え, 無視して取り扱って いる.

b) 埋設管路

実験に使用した管路は， $\phi 150$ UPVC 管で RR 継手 を有している，管路諸元を表一1に示す，一般的な管長 は $5.0 \mathrm{~m}$ であるが，地盤急変部などでは継手効果を生 かし管体応力の低減を計るために短管を用いる場合が多 く, 本実験でも $2.0 \mathrm{~m}$ の短管を使用している. 図一2は 実験に用いた UPVC 管の RR 継手の概要図を示してい る. 図一3に RR 継手の回転特性および伸縮特性を示し ている．管路は電気ケーブル用を想定しており，構造上

表一1＼cjkstart塩化ビニル (UPVC) 管路諸元

\begin{tabular}{|c|c|c|c|}
\hline 管種 & \multirow{2}{*}{ 従来型管路 } & \multicolumn{2}{|c|}{ 開 発 管 路 } \\
\hline 諸元 & & 增肉 1 段目 & 増肉 2段目 \\
\hline 呼径(mm) & 150 & & \\
\hline 外径 (mm) & 170.5 & 190.1 & 209.7 \\
\hline 内径 $(\mathrm{mm})$ & & 150.9 & \\
\hline 肉厚 $(\mathrm{mm})$ & 9.8 & 19.6 & 29.4 \\
\hline 断面2次 $E-X\}$ & 1600 & 3865 & 6947 \\
\hline ホアソン比 & & 0.37 & \\
\hline 弾性係数 $\left(\mathrm{kgf} / \mathrm{cm}^{2}\right)$ & $\begin{array}{c}300000 \\
(2940)\end{array}$ & $\begin{array}{c}22500 \\
(2205)\end{array}$ & $\begin{array}{c}15000 \\
(1470)\end{array}$ \\
\hline 許容応力 $\underset{(\mathrm{MPa})}{\left(\mathrm{kgf} / \mathrm{cm}^{2}\right)}$ & & $\begin{array}{r}330 \\
(32.34)\end{array}$ & \\
\hline 継手の名称 & & $\mathrm{RR}$ & \\
\hline 許容回転角 (deg) & & 2.5 & \\
\hline
\end{tabular}

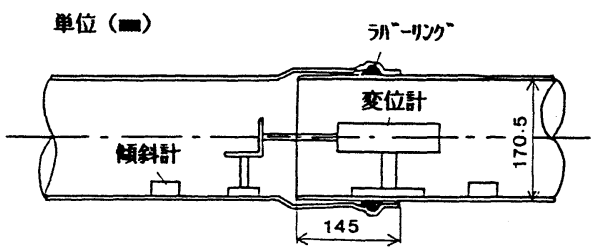

図一2 RR 継手概要図

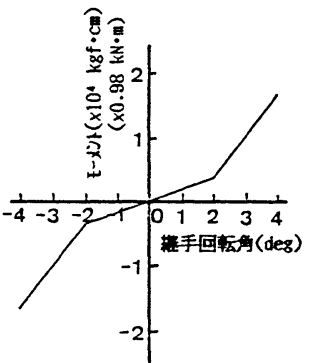

（A）回転特性

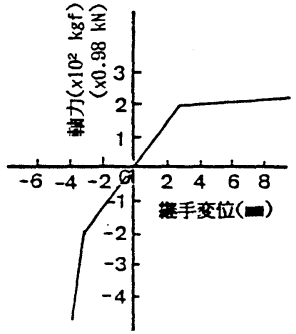

（B）伸編特性
図一3 RR 継手特性 


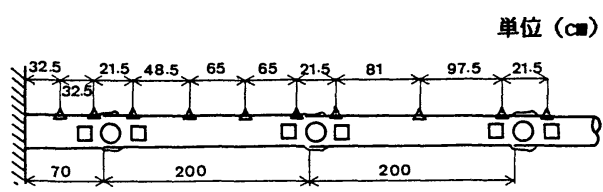

Case (A)

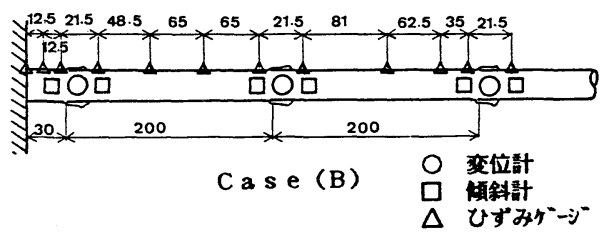

図一4 従来型管路概要図

表一2 測定計器および項目

\begin{tabular}{|c|c|c|c|}
\hline \multicolumn{3}{|c|}{ 测定計器 } & 测定項目 \\
\hline ひずみゲージ & 共和電 & EKFW-5-D16-11 & 管軸・周方向ひずみ \\
\hline 回転計 & 11 & AS-2GA & 継手回転角 \\
\hline 変位計 & 11 & $D A-50 A$ & 継手伸縮量 \\
\hline 変位計 & 11 & DT-10D & 管偏平率 \\
\hline 土压計 & 11 & $\mathrm{BE}-5 \mathrm{KC}, 2 \mathrm{KM}$ & 管体表面の土压 \\
\hline ひずみ测定器 & 11 & UCAM-5A & E \\
\hline
\end{tabular}

の許容継手回転角は $4^{\circ}$ であるが，管路内のケーブル防 護のため許容継手回転角を $2.5^{\circ}$ で取り扱う.

図一4には, 従来型の UPVC 管路の形状を示してい るが, Case (A) では, マンホール取付管路 (以下, 取 付管路と略す）の長さが $70 \mathrm{~cm}$ のもの，またCase（B) では，その長さが $30 \mathrm{~cm}$ のものである.このように取 付管路長さを違えた実験を行っているのは，この長さが 管体応力, 継手回転角に大きな影響を与えており, 最大 地盤沈下量に耐えられる長さを検討するためである.

c) 測定計器

測定項目および用いた計器を表一2に示す．主な測定 内容は管体ひずみ（軸方向および円周方向）, 継手回転 量・伸縮量, 管路沈下量であり, 各測定点の位置は図一 4 に併記してある. さらに, 継手付近の計器取付けは図 -2に詳細に記している.ひずみゲージ以外のリード線 は管内を通って両端部から取り出し，ひずみ計測器に接 続している．管路変位量は，土を被せる前に管頂に目盛 り付きのピアノ線を取り付け, 各沈下量ごとにその変位 量を読むことで測定している.

d) 地盤特性

実験に用いた土は真砂土：山砂＝1：・1の混合砂であ る.その土質特性および粒径過積曲線を図一5に示す.

e) 管路の敷設

沈下土槽底面から $20 \mathrm{~cm}$ まで土を敷いて締め固めた 地盤上に管路を設置した．次いで所定の位置に測定計器 を取り付け，その後管を接続した。次に管頂より $20 \mathrm{~cm}$ ごとに土を埋め戻し，締固めを行い $1.0 \mathrm{~m}$ の土被り厚

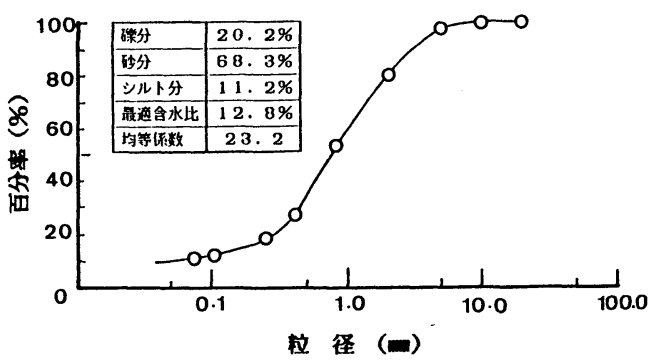

図一5 実験に用いた土の粒径過積曲線

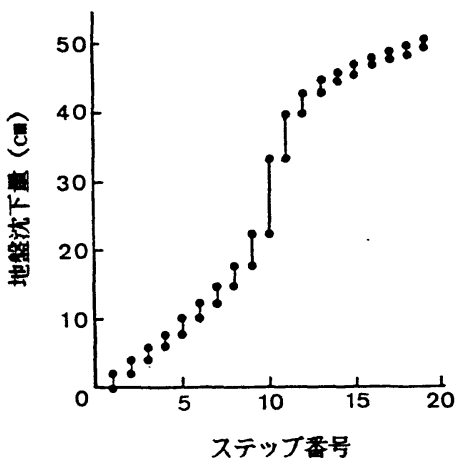

図一6地盤沈下ステップ

さとした. また，各層に石灰層を約 $3 \mathrm{~cm}$ の厚みで敷き 詰め地盤の変形状態を実験後確認できるようにした．地

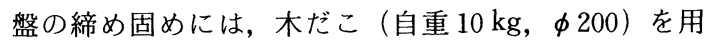
いており, 締固め度はJIS A 1210 の第 1 法を基準とし て, 平均 $90.5 \%$ である.

f）地盤沈下量とその測定

土槽の沈下量は，将来的に管路が敷設される可能性が ある埋立地の野外圧密沈下観測デー夕をもとに, 全沈下 量 $50 \mathrm{~cm}$ を 19 ステップに分けて沈下させた（図一6). 種々の測定は各ステップ沈下 5 分後に行っている.

（2）実験 結果

a) 管体応力

実験では，管路の軸方向および円周方向のひずみを測 定し，次式を用いて管体応力を算定している.

$$
\begin{aligned}
& \sigma_{x}=E \frac{\varepsilon_{x}+\nu \varepsilon_{y}}{1-\nu^{2}} \\
& \sigma_{y}=E \frac{\nu \varepsilon_{x}+\varepsilon_{y}}{1-\nu^{2}}
\end{aligned}
$$

ここに， $\sigma_{x}, \sigma_{y}$ : 軸方向および円周方向応力 $(\mathrm{Pa}), \varepsilon_{x}$, $\varepsilon_{y}$ : 計測軸ひずみおよび円周方向ひずみ $(\mu), E:$ 管体 の弾性係数 $(\mathrm{Pa}), \nu$ : 管体のポアソン比,である.

図一7にCase (A), (B) の各沈下ステップにおける 管頂軸方向最大応力と地盤沈下量の関係を示している.

Case (A), (B) とも最大応力はマンホール取付部付近 の管路に生じている.この値は, 従来実施された $\phi 100$ 


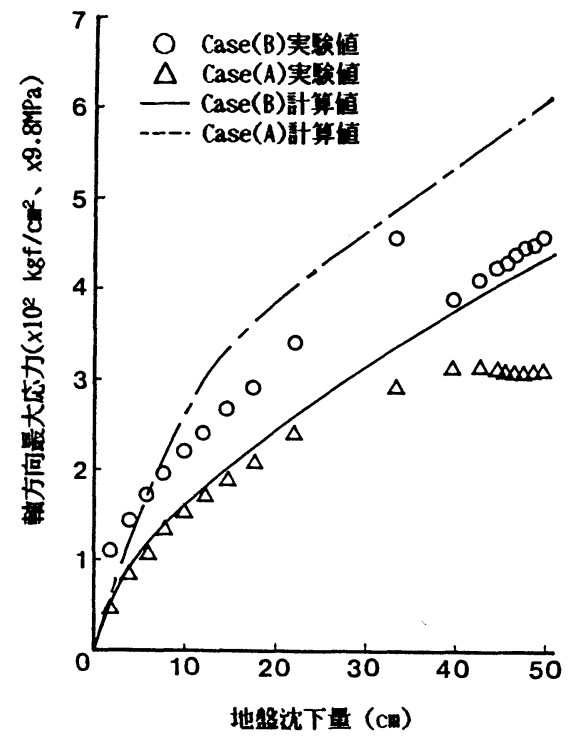

図一7地盤沈下量と軸方向最大応力の関係（従来型管路）

の塩化ビニル管の直線管路部で地盤沈下を受ける実験 ${ }^{21}$ の約 2 倍程度である. 管径が大きくなると曲げ応力が低 下することを考え合わせると, マンホール取付部での沈 下は，直線管路部における沈下よりも大きな応力を発生 させることがわかる. また, 取付管路長さの短い Case (B) の方が最大応力が大きくなっているが, Case (A) ではマンホール取付部付近での測定点が，端部より $32.5 \mathrm{~cm}$ 離れており，もつと端部側で測定していればさ らに大きな応力が発生していたとも考えられる.また， 地盤沈下量の増大に伴い管体応力の増加割合が徐々に小 さくなっているが, これは地盤破壊に伴う地盤反力の低 下が原因と考えられる．さらに地盤沈下量が大きくなっ た時点で, 最大応力がかえって低下する現象が起きてい るが，これは沈下量の増大に伴い土塊の崩落が起こり， 土圧が管路の取付部にさほど作用しなくなったためと考 えられる.

b) 継手回転角

図一8に継手回転角と地盤沈下量の関係を示してい

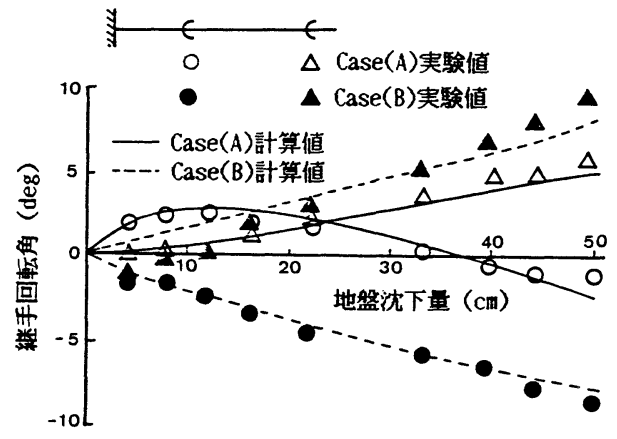

図一8 地盤沈下量と継手回転角の関係（従来型管路）
る. 継手回転角は, マンホール端から 1 番目と 2 番目の 継手について示しており, 3 番目の継手回転角は他の継 手に比べ非常に小さい值であり，無視して取り扱う.

Case (A) での 1 番目の継手は, いったんは正の回転角

（下に凸）を示すが，地盤沈下が増大するにつれて負の 回転角（上に凸）になってきている.これは，マンホー ル取付管の長さが比較的長いため, 沈下量の小さい段階 では取付管が主に変形するが，逆に Case (B) のよう に取付管の長さが比較的短いときは, 沈下量の小さい段 階から継手の回転で応力を逃がしているためと考えられ る.

\section{c) 継手伸縮量}

図一9に地盤沈下量と継手伸縮量の関係を示してい る. いずれも 2 番目の継手の引抜量が大きく, 地盤沈下 量 $45 \mathrm{~cm}$ のところで約 $4 \mathrm{~cm}$ であった．このことより変 形による軸応力はかなり低減されていると考えられ, 測 定された管頂軸方向応力は, 曲げ応力によるところが大 きいと思われる. 後述する数値解析では, 曲げ応力につ いて実験値と比較している.

d）地盤変形およびクラック

図一10にCase (A) の実験における地盤の最終変形 状態を示す. 管路と地盤の変形状態は似ており, 管路上 載土が沈下に伴い上方に押し上げられている様子が伺わ れる.ただし，マンホール近傍の土塊は，地盤の沈下と ともに生ずるマンホールと地盤間の亀裂のために崩落し

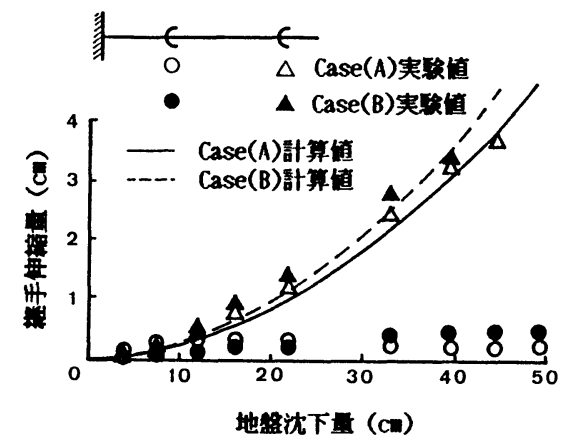

図一9地盤沈下量と継手伸縮量の関係（従来型管路）

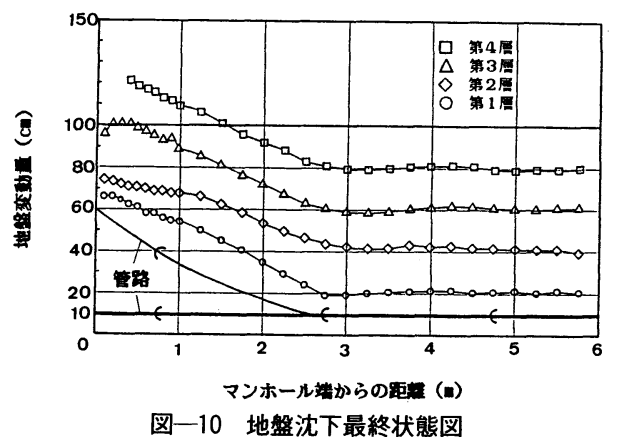




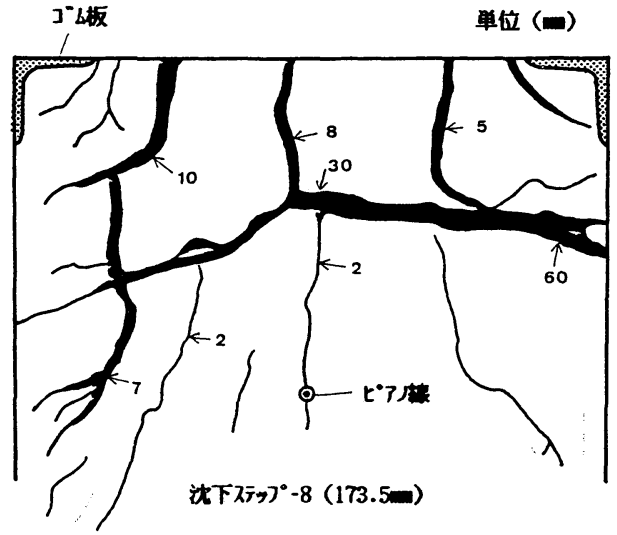

図一11地表面クラックの状態図

\section{ている部分もある.}

また，図一11に地盤表面で観測されたクラックの状 態を示している. 地表面のクラックは沈下量 $40 \mathrm{~mm}$ の 時点から目でとらえることができ， $173.5 \mathrm{~mm}$ 沈下時に は大きいところでは幅 $60 \mathrm{~mm}$ にも達し，地盤が破壊さ れている.このことより，管路鉛直方向の地盤と管路と のすべり限界を約 $40 \mathrm{~mm}$ とみなし, 後述する数值解析 にもその值を採用している.

\section{3. 従来型管路沈下挙動シミュレーション}

\section{（1）解析手法}

著者らによって開発された ERAUL プログラムに よって地盤沈下を受ける管路の挙動をシミュレートし た. ERAUL は弾性床上のはり理論をもとに伝達マト リックス法を用いてプログラムされている. また，非線 形性は荷重増分法を用いて考慮できるようになってい る.さらに，継手特性をも考慮できる，しかし，はり理 論であるので軸方向と軸直角方向の物理量は別々に解析 される. 本論文では, 実験結果より軸方向の応力は継手 により緩和されたとして管軸直角方向のみで取り扱って いる. また, 管体の変形による管軸方向変位は, すべて $1 つ の$ 継手の抜け出しで受け持たれるとして継手伸縮量 を算定している.

\section{（2） 解析モデル}

a) 管路モデル

解析に用いた管路モデルは，図一4に，またその特性 値に関しては表一1にすでに示してある，さらに，実験 では沈下量が増大するとマンホール端付近の管体に白化 した筋がみられたことより，管体は塑性域に入っていた ものと思われる。しかし，解析では管体材料特性を線形 として取り扱っているので，その非線形特性を導入する ため, マンホール端から $30 \mathrm{~cm}$ の区間の管体弾性係数 を1/4 に低下させている.この低下率と範囲は, 解析值
が実験値に近づく最適解を繰り返し計算で求め, そのと きの值を採用している.

b) 継手モデル

解析に用いた継手モデルは，図一4に示す RR 継手で ある・

c）地盤ばね係数

地盤ばね係数は次式で与えた。

$$
K=k \cdot \pi \cdot D
$$

ここに，K：地盤ばね係数， $k$ : 地盤ばね定数， $D:$ 管 路の外径，である。ここで，ガス導管耐震設計指針 ${ }^{8)}$ で は管軸值角方向の地盤と管の相対変位量のすべりを考慮 せず弾性地盤としているが，本論文では実験での地盤破 壊を考慮してクラックの発生し始めた $4 \mathrm{~cm}$ をすべり限 界として，バイリニアで地盤ばね定数をモデル化してい る。また，特にマンホール近傍の地盤は管体の押し上げ 作用により他の地盤に比べ地盤破壊（図一11参照）が 進んでおり，解析にはマンホール近傍の地盤ばね定数を 他の部分より低下させることで考慮している．図一12 に地盤ばね定数の管軸方向分布を示す。なお，地盤ばね 定数値についても解析值と実験値の比較からその最適解 を用いている.

\section{（3）数值シミュレーション結果}

以下に, 従来型 UPVC 管路の実験結果と数値解析結 果の比較を行う。図一13 は $15 \mathrm{~cm}$ 沈下時の実験值と解 析值を比較した管体応力分布を示している.また，図一 8 に地盤沈下量と継手回転角の関係を，さらに図一9に 地盤沈下量と継手伸縮量の関係を併記している．これら も，全体的によい一致を示している.

本論文で用いた地盤条件，端部管路の剛性に関しては すでに述べたように実験值と解析值が一致するように定 めたものであるが，両ケースとも同一の解析条件で実験 值とのよい一致を示していることを考えると，他の夕イ

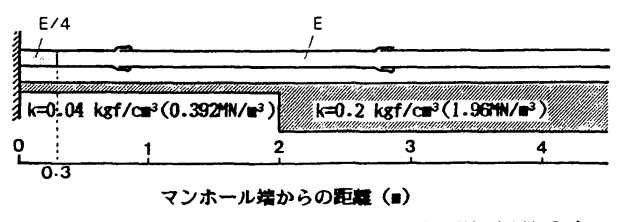

図一12 地盤ばね定数分布および管体弾性係数分布

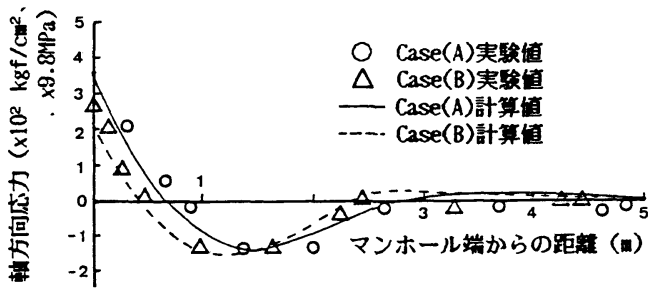

図一13 $15 \mathrm{~cm}$ 沈下時の軸方向応力分布（従来型管路） 


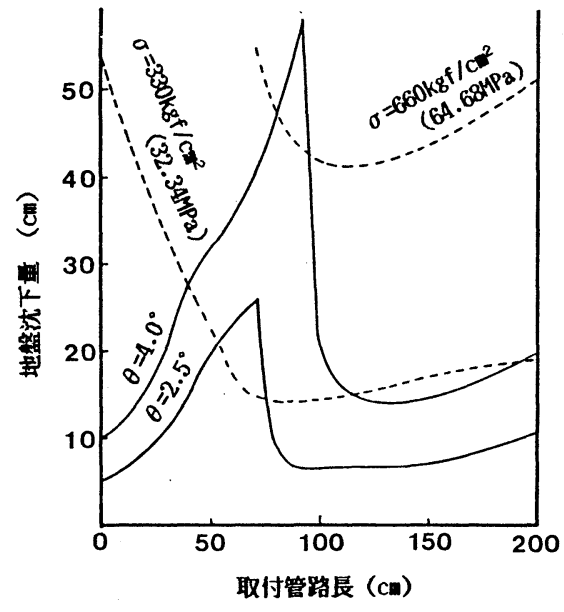

図一14 地盤沈下量と取付管路長の関係（従来型管路）

プの UPVC 管路が地盤沈下を受けたときの挙動を同一 条件の解析で十分予测できることを示唆していると思わ れる.

\section{(4) 最適継手位置}

Case (A), (B) の最大曲げ応力と継手回転角のうち, 取付管路長が短いと継手回転角が，また長いと端部の応 力が先にそれぞれの許容值に達する．すなわち，両制限 を満たし最大の地盤沈下量に耐える最適継手位置がある と考えられる ${ }^{9)}$. そこで, 数值シミュレーションでその 最適位置を求める.

図一14に取付管路長を変えてそれぞれの許容値に達 するときの地盤沈下量を示している．図より許容継手回 転角による制限で, 許容地盤沈下量が急激に低下してい るが，これは図-8ですでに示したように，取付管路長 が短いと負の回転角の制限であるが，長くなると沈下量 の小さい段階で正の回転角により制限されるためであ る. すると, 継手位置 $50 \sim 75 \mathrm{~cm}$ が従来型管路で最適 の設計といえよう.

\section{4. 地盤沈下対策管路の実験および解析}

\section{（1）対策管路の概要}

より大きな地盤沈下に耐え得る管路にするためには, 管体に発生する応力を低下させることと, 継手回転角を 許容值以下にすることである. そこで，管体曲げ剛性を 高め端部での応力を低減するよう管厚を増肉する方式 (以下，対策管路と略す）を考えた。これは，大石 ${ }^{6)}$ が 提案している管路の下に沈下防止板を設け，地盤の変形 を拘束するのと等価な意味を有しており，さらに施工し やすさのうえでは従来と変わらない点で有利と思われ る.

図一15には，対策管路の形状を示しているが，これ
単位 (ca)

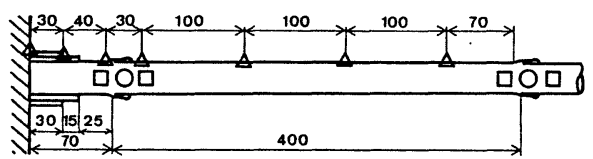

Case (C)

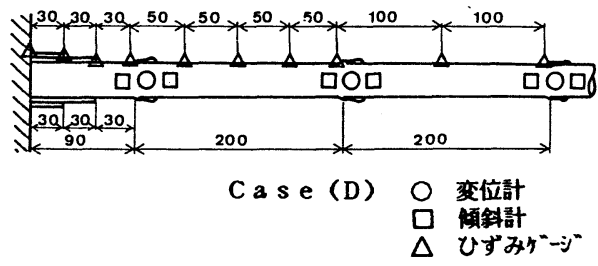

図一15 対策管路概要図

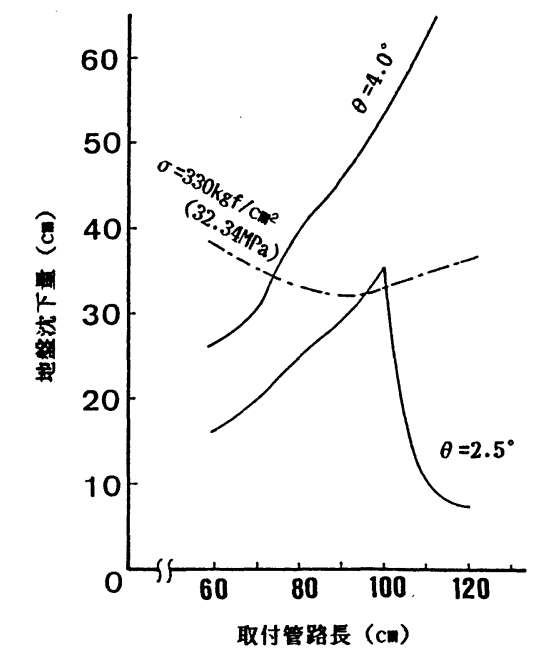

図一16 地盤沈下量と取付管路長の関係（対策管路）

らはマンホール取付管路が 3 つの異なった径より作られ たもので, Case (C) では, 取付管路長が $70 \mathrm{~cm}$ であり， 2 番目の管径までが $30 \mathrm{~cm}, 3$ 番目までが $45 \mathrm{~cm}$ となっ ている.また，Case (D) では取付管路長が $90 \mathrm{~cm}$ で, 2 番目の管径までが $30 \mathrm{~cm}, 3$ 番目までが $60 \mathrm{~cm}$ となっ ている.ここで, マンホール端からの継手の位置の決定 は, 図一14 と同様の手法を用いあらかじめ数值解析よ り最適継手位置を推定している (図一16参照). また, 管径の変化している増肉部では次式により管体剛性が変 化する.

$$
E_{z}=E\left(-0.25 \frac{t_{z}}{t}+1.25\right)
$$

ここに, $E_{z}$ : 対策管路の弾性係数, $t_{z}$ : 対策管路の肉厚, $t$ : 従来型管路の肉厚, である. 表一1にUPVC 管の増 肉部での特性值を併記してある.

\section{（2）実験および数值解析結果}

図一17，18 に実験值と解析值の応力分布および継手 回転角を示している. マンホール近傍の応力は複雑で十 


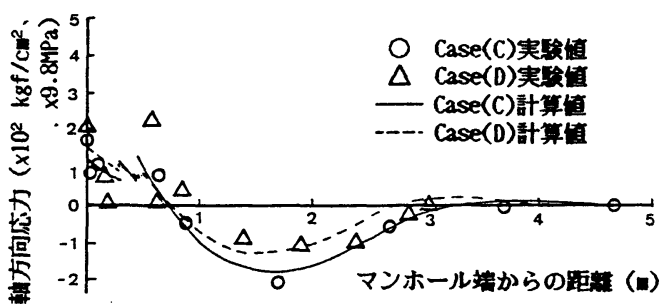

図-17 $15 \mathrm{~cm}$ 沈下時の軸方向応力分布（対策管路）

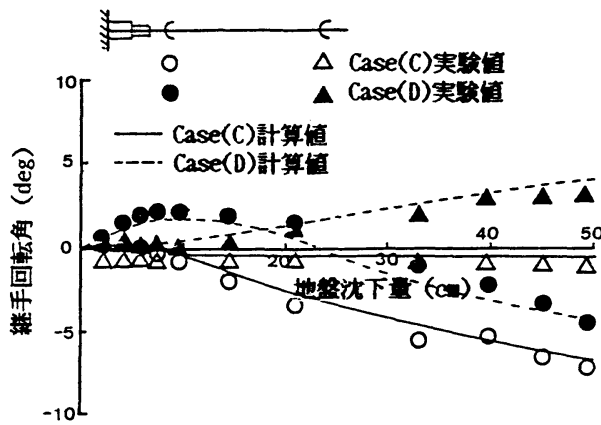

図一18地盤沈下量と継手回転角の関係（対策管路）

分には一致していない．この原因として，対策管路は従 来管に管径の大きくした管を接着することで作られてお り, 変形に伴い接着部に多少のすべりが生じ, デー夕が ばらついたのではないかと思われるが，全体的には実験 値と解析値はよい一致を示している，さらに，対策管路 では最大応力がマンホールから 2 本目の管路中央付近に 発生しているのが特幑である．また，継手回転角は従来 管のときと同様にほぼ実験値と解析值は一致している. この実験結果より対策管路においても従来型と同じ条件 下の数值解析で十分な精度が得られることが知られた。

図一16より対策管路の取付管路最適長さはほぼ90 100 $\mathrm{cm}$ の範囲にあれば，約 $30 \mathrm{~cm}$ の地盤沈下には耐え得る と考えられる.

これらの事実を踏まえたうえで，さらに数值解析によ り最適な沈下対策を考える.

\section{（3）耐沈下最適管路}

発生応力が大きい部位は管路の増肉で曲げ剛性を高め るとの考えより，2 本目の管路に対しても増肉を施した 種々の管路モデルに対し数值解析を行った.そのなかで, 最大の沈下量に耐える耐沈下最適管路モデルおよび許容 応力に達する $45 \mathrm{~cm}$ 沈下時の応力分布, さらに地盤沈 下量と継手回転角の関係を図一19，20に示している.

この場合, 通常の対策管路で最大 $30 \mathrm{~cm}$ 程度しか地盤 沈下に耐えられないのに対し，2 本目の管路を増肉する だけで約 $45 \mathrm{~cm}$ までの沈下に耐え得ることを示してい る.

上記の結果より，地盤沈下を受ける管路の管体自体の
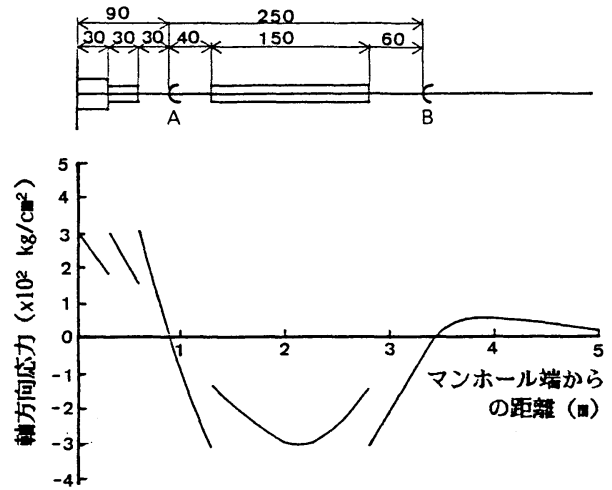

図一19 $45 \mathrm{~cm}$ 沈下時の軸方向応力分布（耐沈下最適管路）

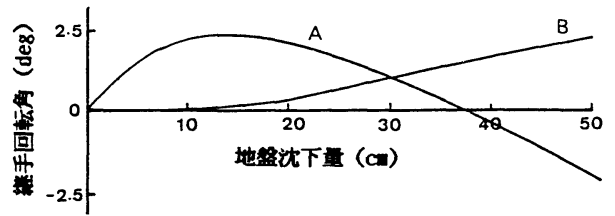

図一20 地盤沈下量と継手回転角の関係（耐沈下最適管路）

対策は,応力集中部に対しては管体に高い剛性をもたせ， 継手を有する場合は，マンホール端からの継手の配置を 最適化することが肝要である.

（4）埋設深さに対する従来型および対策管路の取付 管路長

本研究での管路埋設深さは $1 \mathrm{~m}$ であるが，実施工時 には地形や他の管路との関係より必ずしも $1 \mathrm{~m}$ に埋設 されるとは限らない，また，埋設深さの違いにより管路 に作用する土圧も異なってくるため, 本研究で得られた 結果がそのまま適用できるものではない，一方，地盤種 別の違いについては，実際に沈下現象が発生する地盤は ほぼ同様の地盤条件を有していると考えられ，かつ埋設 管路敷設時には管路周辺土は砂質土で置き換えられるこ とを考え合わせると，その影響は無視して取り扱っても 差し支えないと思われる．ここで，埋設深さの変化に対 する取付管路長を求めることを次に考える.

埋設深さの影響は, 本解析手法において地盤ばね定数 に直接的に関係する．そこで，本論文では以下の仮定に 基づいて埋設深さの影響を考慮した．まず，地盤と管路 のすべり限界相対変位量は, 土質が一定であれば変化し ないとして $4 \mathrm{~cm}$ とし, 一方, 地盤ばね定数 $k$ と埋設深 さ $H$ との間には次式の関係が成り立つとしている ${ }^{11)}$.

$$
k=\alpha\left(C+\gamma_{t} \cdot H \cdot \tan \phi\right)
$$

ここに, $\alpha$ : 比例定数, $C$ : 地盤の粘着力, $\gamma_{t}$ : 地盤の 単位体積重量, $H$ : 埋設深さ, $\phi:$ 地盤の内部摩擦角, である.また， $H=100 \mathrm{~cm}$ で $k=0.2 \mathrm{kgf} / \mathrm{cm}^{3}(1.96$ $\left.\mathrm{MN} / \mathrm{m}^{3}\right), \quad \gamma_{t}=1.7 \mathrm{gf} / \mathrm{cm}^{3}\left(1.67 \mathrm{kN} / \mathrm{m}^{3}\right), \phi=37^{\circ}, C=$ 


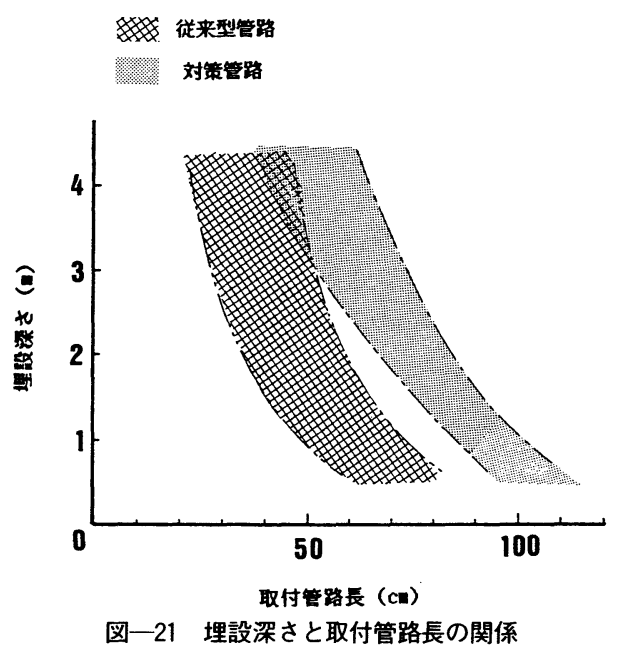

0 , として $\alpha=0.00165$ と求めた.これより, 任意の埋 設深さに対して地盤ばね定数を定め, 前述と同様に従来 型管路に対して最適取付管路長を求めるための数値計算 を行った。

従来型管路と対策管路における，約 $4 \mathrm{~m}$ の埋設深さ までに対する最適取付管路長さを図一 21 に示している. ここで，すでに図一8に示したように，取付管路長が長 くなると 1 番目の正の継手回転角の最大值が大きくなる が, さらに埋設深さが深くなると地盤による管路変形の 拘束が強くなり，その正の最大值がさらに大きくなる. このため，埋設深さが深くなるほど，最適取付管路長が 短い段階で許容回転角に達することになる，すなわち， 埋設深さが増大すると最適管路長は短い方が有利と考え られる。なお，対策管路の計算においては，各増肉部長 さの比率を同じとして取り扱っている.

\section{5. 結 論}

本研究は，マンホールに取り付けられた $R R$ 継手を 有する $\phi 150$ 塩化ビニル管路の沈下挙動を, 実験および 数值シミュレーションにより明らかにしている.さらに, 地盤沈下対策としての管路開発を数值シミュレーション で行い，かつ実験で検証している．以下，得られた知見 を要約する.

（1）マンホール際管路の沈下実験より，管軸方向最 大応力は管路取付部に集中する.さらに，取付管路長を 違えた実験より，取付管路長が短いと最大応力はかなり 低减されるが，その分負の継手回転角の増大をきたし， 許容継手回転角を越してしまう。また，取付管路長が長 いと地盤沈下量が小さい段階で，正の回転角で許容値を 越えることが知られた。

（2）実験結果と ERAUL プログラムを用いた非線 形解析結果は, 沈下量ごとの応力分布, 継手回転角とも
よい一致を示す.

（3）従来型管路では，許容応力・継手回転角の両制 限を満足する最適取付管路長を設定することで, $15 \mathrm{~cm}$ 程度の地盤沈下に耐え得ることができる．また，応力の 集中するマンホール近傍の管体剛性を高めた対策管路に 対し最適取付管路長を設定すると，従来型管路に対し約 2 倍の地盤沈下に耐え得ることができる.さらに，対策 管路において 2 本目の管体剛性をも高めた耐沈下最適管 路を用いると，従来型管路に対し約 3 倍の地盤沈下まで 耐えることができる。

（4）最適取付管路長は，埋設深さが深くなるほど短 い方が有利である.

（5）本研究の手法を用いると，他の管種・管径・継 手特性を有する管路に対しても，同様に耐沈下最適管路 を開発することが可能である.

謝辞：本研究において，沈下実験およびデータ整 理に携わった関係各位に厚く御礼を申し上げます。

\section{参 考 文 献}

1）菊池征也・安延信一・伊原陽二：地中管路の強制沈下実 験について, 第 36 回土木学会年次学術講演会, pp. 466 $\sim 467,1981.10$

2）高田至郎・山部泰男：沈下土槽による埋設管路の大変形 挙動実験とその解析，土木学会論文報告集，第 323 号， pp. $55 \sim 65,1982.7$.

3）高田至郎・高橋俊二・山部泰男：硬質塩化ビニル管の地 震時挙動シミュレーション, 水道協会雑誌，第 547 号, pp. $27 \sim 32,1980$.

4）日本ガス協会：ガス工作物設置基準調査委員会資料（大 口径軸直角方向沈下実験)，pp.119 140.

5）水道用塩ビ管の技術研究会：ゴム輪形硬質塭化ビニル管 の埋設武験等に関する研究報告書, 1984.6.

6）大石 博：地盤沈下を受ける埋設管路の挙動に関する二, 三の考察, 土木学会論文報告集, 第 356 号, pp. 379 386, 1985. 4 .

7） 岡 孝則：地盤変状を受ける埋設管路の動的挙動に関す る基礎的研究, 神戸大学卒業研究, 1983.2.

8）日本ガス協会：ガス導管耐震設計指針，pp. 350 421, 1982.3.

9）高田至郎・田邊揮司良・中野雅弘・沢橋剛志・暒本俊彦 : 液状化を受ける通信用管路の挙動解析之地震対策, 建 設工学研究所報告, 第 26 号, 1984. 12.

10) Hazama, Y., Ito, T., Yamajyo, K., Irioka, H., Takada, S. and Ueno, T. : Development of Manhole Fitting Unplasticized Polyvinyl Chloride Pipeline System Resisting to Ground Subsidence, P.V.P. Conference, Vol. 98-4, pp. 55 60, 1985.

11）西尾宣明：埋設管に加わる荷重と応力について，配管技 術, 1976.7 .

(1986.3.12 • 受付) 